\begin{tabular}{lcccc|cr} 
Volume & 13, & Nomor 1, & Mei 2021, & pp 84-98 & \multicolumn{2}{c}{ Copyright ${ }^{\circ} 2017$} \\
Jurnal & Akuntansi, & Program & Studi & Akuntansi, & Fakultas & Bisnis, \\
Universitas & Kristen & Maranatha. & ISSN & $2085-8698$ & e-ISSN & $2598-4977$.
\end{tabular}

http://journal.maranatha.edu

\title{
Revaluasi Aset Tetap pada Perusahaan Sektor Industri Manufaktur di Indonesia
}

\author{
Chandra Ferdinand Wijaya \\ Fakultas Ekonomi Program Studi Akuntansi - Universitas Katolik Parahyangan \\ (Jalan Ciumbuleuit No. 94, Bandung) \\ chandra.ferdinand@unpar.ac.id
}

\begin{abstract}
IFRS was formed which is expected to improve the quality of financial reporting and enchance comparability of financial information for decision making. Indonesia is one of the countries that adopted IFRS. One of the IFRS standard adopted by Indonesia is the fixed assets accounting standard as outlined in PSAK 16. PSAK 16 explains that the measurement of fixed assets can be done by choosing between cost models or revaluation models. This study is intended to provide development of fixed asset measurement models that tend to be used by the manufacturing companies in Indonesia along with the reasons underlying to apply the related fixed asset measurement model. This research is an analytical descriptive study conducted on manufacturing companies listed on the Indonesia Stock Exchange from 2015 until 2017. The result shows that most of the manufacturing companies in Indonesia still use the cost model in the measurement of fixed assets for financial reporting. Nonetheless, there are already several manufacturing companies that implement fixed asset revaluation models and the number has increased from year to year. With this in mind, the revaluation model for fixed assets is growing and the role of asset valuation services is felt to be increasingly needed.
\end{abstract}

Keywords: Cost Model, Fixed Asset, IFRS, PSAK 16, and Revaluation Model

\begin{abstract}
Abstrak
IFRS sebagai standar akuntansi keuangan diharapkan dapat meningkatkan kualitas pelaporan keuangan dan meningkatkan daya banding informasi keuangan untuk pengambilan keputusan. Indonesia merupakan salah satu negara yang mengadopsi IFRS. Salah satu standar IFRS yang diadopsi oleh Indonesia adalah standar akuntansi aset tetap sebagaimana diatur dalam PSAK 16. PSAK 16 menjelaskan bahwa pengukuran aset tetap dapat dilakukan dengan memilih antara model biaya atau model revaluasi. Penelitian ini ditujukan untuk memberikan gambaran mengenai perkembangan model pengukuran aset tetap yang cenderung digunakan
\end{abstract}


oleh perusahaan manufaktur di Indonesia beserta alasan yang mendasari penerapan model pengukuran aset tetap terkait. Penelitian ini merupakan penelitian deskriptif analitis yang dilakukan pada perusahaan manufaktur yang terdaftar di Bursa Efek Indonesia dari tahun 2015 hingga 2017. Hasil penelitian menunjukkan bahwa sebagian besar perusahaan manufaktur di Indonesia masih menggunakan model biaya dalam pengukuran aset tetap untuk pelaporan keuangan. Meski demikian, sudah ada beberapa perusahaan manufaktur yang menerapkan model revaluasi aset tetap dan jumlahnya terus meningkat dari tahun ke tahun. Dengan hal tersebut, model revaluasi aset tetap dinilai akan semakin berkembang dan peran jasa valuasi aset dirasa semakin dibutuhkan.

\section{Kata Kunci: Model Biaya, Aset Tetap, IFRS, PSAK 16, dan Model Revaluasi}

\section{Pendahuluan}

Setiap negara memiliki standar akuntansinya masing-masing. Standar akuntansi dari suatu negara tentunya memiliki beberapa perlakuan akuntansi yang berbeda dengan standar akuntansi yang berlaku di negara lainnya. Sebagai dampaknya, informasi yang disajikan dalam laporan keuangan perusahaan antar negara yang satu dengan negara yang lainnya menjadi kurang seragam dan sulit untuk diperbandingkan.

Seiring dengan adanya

perkembangan globalisasi, transaksi perusahaan lintas negara semakin banyak, baik transaksi perdagangan, pinjam meminjam, investasi, maupun transaksi lainnya. Semakin banyaknya transaksi lintas negara menandakan adanya suatu kebutuhan atas standar akuntansi yang memungkinkan perusahaan-perusahaan untuk menghasilkan suatu laporan keuangan dengan format dan perlakuan akuntansi yang seragam. Hal ini diperlukan agar informasi yang tersaji pada laporan keuangan dapat dibandingkan sehingga memudahkan pengguna laporan keuangan dalam menggunakan informasi tersebut untuk pengambilan keputusan. Salah satu keputusan yang harus mempertimbangkan informasi laporan keuangan adalah keputusan terkait alokasi dana, yang tidak terbatas pada perusahaan lokal dan nasional, tetapi dapat melibatkan lingkup internasional. Sebagai tindak lanjut dari hal tersebut, maka dibentuk standar akuntansi internasional yang disebut dengan IFRS (International Financial Reporting Standard).

Penerapan IFRS diharapkan dapat memudahkan pengguna untuk memahami informasi yang disajikan laporan keuangan karena adanya keseragaman standar akuntansi keuangan yang berbasis internasional. Dengan demikian, perusahaan dapat meningkatkan arus investasi global secara transparan dan memperoleh kesempatan untuk mendanai operasionalnya melalui pasar modal secara global dengan biaya modal yang tidak terlalu mahal (Rahmawati \& Murtini, 2015).

IFRS merupakan standar akuntansi internasional yang mulai diadopsi Indonesia semenjak tahun 2008 ke dalam standar akuntansinya, yaitu SAK (Standar Akuntansi Keuangan) dan diimplementasikan hingga sekarang. Tahapan konvergensi IFRS terhadap SAK Indonesia terdiri atas 3 tahap, yaitu: tahap adopsi, tahap persiapan, dan tahap implementasi (Saputra \& Hermawan, 2012). Tabel berikut merupakan rincian mengenai tahap-tahap konvergensi IFRS di Indonesia beserta periode waktunya. 
Tabel 1

Tahap-Tahap Konvergensi IFRS di Indonesia

\begin{tabular}{|c|c|c|}
\hline Tahap & Waktu & Penjelasan \\
\hline Adopsi & $\begin{array}{c}2008- \\
2010\end{array}$ & $\begin{array}{l}\text { Pada tahap ini, } \\
\text { dilakukan } \\
\text { persiapan } \\
\text { terkait proses } \\
\text { adopsi IFRS ke } \\
\text { SAK dan } \\
\text { evaluasi } \\
\text { dampak adopsi } \\
\text { terhadap SAK }\end{array}$ \\
\hline Persiapan & 2011 & $\begin{array}{l}\text { Pada tahap ini, } \\
\text { dilakukan } \\
\text { penyelesaian } \\
\text { infrastruktur } \\
\text { untuk } \\
\text { konvergensi } \\
\text { IFRS serta } \\
\text { mulai dilakukan } \\
\text { penerapan } \\
\text { beberapa SAK } \\
\text { berbasis IFRS } \\
\text { secara bertahap }\end{array}$ \\
\hline Implementasi & $\begin{array}{c}\text { dimulai } \\
\text { dari } \\
2012\end{array}$ & $\begin{array}{l}\text { Pada tahap ini, } \\
\text { dilakukan } \\
\text { penerapan SAK } \\
\text { berbasis IFRS } \\
\text { secara bertahap } \\
\text { serta evaluasi } \\
\text { atas dampak } \\
\text { penerapannya } \\
\text { secara } \\
\text { komprehensif }\end{array}$ \\
\hline
\end{tabular}

Sumber: Saputra \& Hermawan (2012)

SAK terdiri atas beberapa PSAK (Pernyataan Standar Akuntansi Keuangan). Setiap PSAK memberikan pengaturan mengenai perlakuan akuntansi untuk rekening akuntansi dan transaksi tertentu. Salah satu PSAK yang mengadopsi ketentuan IFRS adalah PSAK 16 yang mengatur perlakuan akuntansi terkait aset tetap. PSAK 16 ini mengadopsi ketentuan dari IAS (International Accounting Standard), yaitu IAS 16. PSAK 16 mulai mengadopsi ketentuan dari IAS 16 secara bertahap dan diberlakukan efektif per 1 Januari 2008 di Indonesia (Saputra \& Hermawan, 2012).

Sebelum PSAK 16 mengadopsi ketentuan IFRS, perusahaan harus menerapkan model biaya dalam melakukan pengukuran aset tetapnya atau dengan kata lain aset tetap harus disajikan sebesar nilai perolehan dikurangi dengan akumulasi penyusutan pada setiap tanggal pelaporan. Hal tersebut dirumuskan dalam PSAK 16 (1994). Dengan mengadopsi ketentuan dari IAS 16, DSAK IAI menerbitkan PSAK 16 (revisi 2007). IFRS merupakan standar akuntansi internasional yang lebih berfokus pada penerapan akuntansi nilai wajar (Clarkson, et.al., 2011). Dengan diadopsinya ketentuan IFRS ke dalam PSAK 16, maka PSAK 16 (revisi 2007) menjelaskan bahwa perusahaan dapat memilih untuk menerapkan model biaya atau model revaluasi dalam melakukan pengukuran aset tetapnya (Ikatan Akuntan Indonesia, 2017). Ketentuan mengenai pemilihan model biaya atau model revaluasi dalam pengukuran aset tetap ini terus berlaku meskipun PSAK 16 telah direvisi menjadi PSAK 16 (revisi 2015) yang mana merupakan ketentuan mengenai standar akuntansi terkait aset tetap yang berlaku hingga saat ini di Indonesia.

Model revaluasi merupakan model yang lebih terfokus pada penerapan akuntansi nilai wajar (Gunawan \& Nuswandari, 2019). Munculnya model revaluasi sebagai model pengukuran aset tetap tidak membuat perusahaan-perusahaan di Indonesia termotivasi menerapkannya. Hal ini ditunjukkan dengan penelitian yang dilakukan oleh Zakaria (2011). Hasil penelitiannya menunjukkan bahwa perusahaan-perusahaan di Indonesia cenderung menerapkan model biaya sebagai model pengukuran aset tetapnya selama tahap adopsi IFRS. Padahal, penggunaan nilai wajar sebagai dasar pengukuran aset tetap memberikan informasi yang lebih relevan bagi pengguna laporan keuangan sehingga dapat dilakukan pengambilan 
keputusan dengan lebih tepat (Rahmawati \& Murtini, 2015). Tercapainya pengambilan keputusan dengan lebih tepat dan transparan merupakan salah satu tujuan diadopsinya IFRS, namun pada kenyataannya model revaluasi yang merupakan hasil konvergensi dengan IFRS belum diminati oleh banyak perusahaan di Indonesia, khususnya pada masa adopsi IFRS.

Dari sisi perpajakan, revaluasi aset tetap mengharuskan perusahaan untuk membayar pajak penghasilan yang bersifat final. Berdasarkan Peraturan Menteri Keuangan Republik Indonesia Nomor 79/PMK.03/2008, perusahaan yang menerapkan revaluasi aset tetap dikenakan $\mathrm{PPh}$ final sebesar 10\% dari surplus revaluasi. Keberadaan $\mathrm{PPh}$ final tersebut dirasa menambah beban perusahaan sehingga menurunkan minat perusahaan di Indonesia untuk menggunakan model revaluasi sebagai model pengukuran aset tetap karena merasa bahwa manfaat yang diperoleh tidak sebanding dengan biayanya. Padahal penerapan akuntansi nilai wajar yang salah satunya diwujudkan melalui model revaluasi aset tetap dapat memberikan potensi manfaat, baik bagi perusahaan maupun pengguna laporan keuangan lainnya.

Dalam rangka mendorong perusahaan-perusahaan di Indonesia untuk melakukan revaluasi atas aset tetapnya, pemerintah Indonesia menerbitkan Peraturan Menteri Keuangan Republik Indonesia Nomor 191/PMK.010/2015. Menurut peraturan tersebut, keuntungan atau surplus revaluasi dikenakan $\mathrm{PPh}$ final yang besar tarifnya didasarkan atas waktu permohonan pengajuan revaluasi aset tetap. Tarif PPh Final menurut peraturan yang baru tersebut lebih ringan apabila pengajuan revaluasi aset tetap dilakukan pada tahun 2015 dan 2016. Hal ini diharapkan dapat menjadi insentif bagi perusahaan untuk melakukan revaluasi aset tetap demi meningkatkan kualitas informasi laporan keuangannya.

Salah satu industri yang berkembang pesat di Indonesia adalah industri manufaktur.
Sebagai industri yang berkembang, tentunya perusahaan-perusahaan yang bergerak dalam industri tersebut membutuhkan suntikan dana yang cukup besar. Salah satu caranya dengan menerapkan revaluasi aset yang dapat mendorong peningkatan kinerja perusahaan dan tercermin pada laba dan harga saham perusahaan (Hidayat \& Hati, 2017).

Perusahaan yang bergerak dalam sektor industri manufaktur di Indonesia merupakan perusahaan yang relevan untuk dikaji dalam penelitian mengenai revaluasi aset tetap. Hal ini disebabkan karena sektor industri manufaktur di Indonesia merupakan sektor industri yang sedang berkembang pesat dan memiliki peluang untuk memperoleh dana dengan cara revaluasi aset tetap. Selain itu, penelitian yang membahas mengenai banyaknya perusahaan manufaktur di Indonesia yang telah menerapkan model revaluasi aset tetap masih berjumlah sedikit. Oleh karena itu, penelitian ini dimaksudkan untuk meninjau penerapan model revaluasi sebagai model pengukuran aset tetap pada perusahaanperusahaan yang bergerak dalam sektor industri manufaktur di Indonesia.

Penelitian ini merupakan penelitian lebih lanjut dan pengembangan dari penelitian yang dilakukan oleh Zakaria (2011). Penelitian Zakaria (2011) lebih berfokus pada periode adopsi IFRS. Oleh karena minimnya penelitian yang membahas mengenai banyaknya perusahaan manufaktur di Indonesia yang telah menerapkan model revaluasi aset tetap, maka penelitian ini dimaksudkan untuk melihat kembali penerapan model pengukuran aset tetap di perusahaan manufaktur yang terdaftar dalam Bursa Efek Indonesia dan lebih berfokus selama periode implementasi IFRS, khususnya dalam periode 2015 sampai dengan 2017. Hal ini dirasa perlu karena keberadaan peraturan dari Menteri Keuangan Republik Indonesia yang mendorong perusahaan-perusahaan di Indonesia untuk melakukan revaluasi aset tetap. Selain itu, Indonesia telah memasuki 
tahap implementasi dari IFRS. Jumlah penelitian yang masih minim yang mendeskripsikan jumlah perusahaan yang telah menerapkan model revaluasi aset tetap terutama pada periode implementasi IFRS mendorong dilakukannya penelitian untuk menggambarkan kesadaran manajemen perusahaan manufaktur di Indonesia akan potensi manfaat dari penerapan nilai wajar yang direpresentasikan melalui model revaluasi aset tetap, khususnya pada tahap implementasi IFRS selama periode 2015 sampai dengan 2017 yang mana merupakan periode insentif pajak atas revaluasi aset tetap sebagai akibat dari diterbitkannya Peraturan Menteri Keuangan Republik Indonesia Nomor 191/PMK.010/2015.

\section{Kerangka Teoretis}

\section{IFRS (International Financial Reporting Standard)}

Seiring dengan semakin berkembangnya perdagangan bebas dan transaksi lintas negara, perusahaan-perusahaan memerlukan suatu standar pelaporan keuangan yang lebih seragam. Sebagai akibatnya, dibentuklah standar pelaporan keuangan internasional yang disebut IFRS (International Financial Reporting Standard). Hal ini dimaksudkan agar memungkinkan dilakukannya perbandingan kinerja keuangan antar satu perusahaan dengan perusahaan lainnya, meskipun perusahaan tersebut berada dalam negara yang berbeda. Selain dapat diperbandingkan, laporan keuangan akan berguna dalam pengambilan keputusan jika informasinya memiliki karakteristik yang salah satunya disebut sebagai relevan (Wijaya, 2020). Dengan demikian, investor dan kreditor dapat melakukan pengambilan keputusan alokasi dana dengan baik yang tidak terbatas pada perusahaan dalam negeri saja, tetapi juga perusahaan luar negeri. Begitu pula halnya dengan pihak noninvestor dan kreditor, seperti pelanggan, pemasok, dan pihak lainnya yang memerlukan informasi laporan keuangan yang lebih seragam dan relevan untuk pengambilan keputusan ekonomi lainnya.

IFRS sebelumnya merupakan suatu standar akuntansi yang dikenal dengan sebutan IAS (International Accounting Standard). IAS merupakan standar akuntansi internasional yang dibentuk oleh IASC (International Accounting Standard Committee) (Wulandari \& Adiati, 2015). Kemudian, IASC berubah nama menjadi IASB (International Accounting Standard Board) yang memiliki tanggung jawab untuk membentuk standar akuntansi internasional yang kemudian disebut dengan IFRS. Sejak saat itu, standar akuntansi internasional lebih dikenal oleh berbagai negara dan mulai banyak negara yang melakukan adopsi standar akuntansinya dengan IFRS, tidak terkecuali Indonesia yang mulai melakukan adopsi IFRS pada tahun 2008.

IFRS merupakan standar akuntansi keuangan yang bersifat principle-based dibandingkan GAAP negara lain yang bersifat rule-based. Hal ini menunjukkan bahwa penerapan IFRS lebih membutuhkan banyak pertimbangan (judgement) dalam menentukan perlakuan akuntansi dari suatu transaksi agar sesuai dengan substansi dari transaksi tersebut (Jackling, et.al., 2012). Prinsip substansi mengungguli bentuk tersebut diterapkan mengingat semakin dinamisnya ekonomi saat ini dengan berbagai macam transaksi yang ada. Dengan demikian, penerapan substansi mengungguli bentuk diharapkan dapat meningkatkan komparabilitas informasi yang tersaji dalam laporan keuangan dalam lingkungan yang dinamis saat ini.

\section{Akuntansi Aset Tetap}

Akuntansi aset tetap di Indonesia diatur dalam PSAK 16. PSAK 16 yang terkini di Indonesia adalah PSAK 16 (revisi 2015). Menurut PSAK 16, aset tetap merupakan aset berwujud yang dimiliki untuk digunakan dalam kegiatan operasional utama perusahaan, seperti produksi, penyediaan barang atau jasa, penyewaan, atau kegiatan administrasi perusahaan dan 
diprediksi akan digunakan oleh perusahaan dalam jangka waktu lebih dari satu periode (Aryani \& Juliarto, 2017). Aset tetap diakui oleh perusahaan apabila biaya perolehan dari aset tetap tersebut dapat diukur secara andal dan dengan mengeluarkan biaya tersebut, besar kemungkinannya bahwa perusahaan akan mendapatkan manfaat ekonomik dari aset tersebut di masa yang akan datang (Ikatan Akuntan Indonesia, 2017).

Pada saat aset tetap diakui, maka perusahaan akan mengakuinya sebesar biaya perolehan dari aset tetap. Setelah aset tetap diakui, maka perusahaan melakukan pengukuran. Pengukuran setelah pengakuan aset tetap dapat dilakukan dengan memilih salah satu diantara model biaya dan model revaluasi (Ikatan Akuntan Indonesia, 2017).

\section{Model Biaya Aset Tetap}

Perusahaan yang menerapkan model biaya menyajikan aset tetapnya berdasarkan harga perolehan dikurangi dengan akumulasi penyusutan dan akumulasi rugi penurunan nilai (Ikatan Akuntan Indonesia, 2017). Penggunaan model biaya memberikan informasi yang lebih reliabel namun kurang relevan karena informasi aset tetap yang disajikan merupakan informasi harga perolehan yang sifatnya didasarkan atas data masa lalu yang sudah kurang relevan bagi pengguna laporan keuangan (Christensen dan Nikolaev, 2013).

\section{Model Revaluasi Aset Tetap}

Perusahaan yang menerapkan model revaluasi akan menyajikan aset tetapnya sebesar nilai revaluasian, yaitu nilai wajar (fair value) dari aset tetap pada tanggal revaluasi dikurangi akumulasi penyusutan dan akumulasi rugi penurunan nilai setelah tanggal revaluasi (Ikatan Akuntan Indonesia, 2017). Jika suatu aset tetap direvaluasi, maka seluruh aset tetap dalam kelas yang sama harus direvaluasi. Frekuensi revaluasi tergantung dari perubahan nilai wajar aset tetap yang direvaluasi. Untuk aset tetap dengan perubahan nilai wajar aset yang signifikan dengan nilai tercatatnya, maka revaluasi aset tetap umumnya dilakukan setiap tahun. Namun, untuk aset tetap yang perubahan nilai wajarnya tidak signifikan, maka revaluasi aset tetap dapat dilakukan setiap tiga tahun atau lima tahun sekali (Ikatan Akuntan Indonesia, 2017).

Model revaluasi dianggap lebih superior dari model biaya karena informasi aset tetap disajikan dengan menggunakan nilai wajar yang merupakan nilai saat ini sehingga lebih relevan dibandingkan model biaya (Baker, 2011). Relevansi informasi dianggap lebih membantu pengguna laporan keuangan untuk memprediksi potensi arus kas yang dapat dihasilkan perusahaan di masa yang akan datang sehingga dapat membantu pengguna dalam melakukan pengambilan keputusan dengan lebih tepat. Namun, model revaluasi memiliki kelemahan. Karena aset tetap disajikan sebesar nilai wajar, maka ada kemungkinan bahwa nilai wajar yang digunakan dalam penyajian aset tetap kurang reliabel (Baker, 2011). Untuk mendapatkan informasi nilai wajar yang reliabel, perusahaan seringkali menggunakan jasa penilai (Baker, 2011). Penggunaan jasa penilai aset tetap menimbulkan biaya yang nilainya tidak sedikit dan seringkali dirasa memberatkan dan rumit bagi manajemen perusahaan (Maria, 2010).

Penerapan model revaluasi untuk aset tetap mengakibatkan laporan keuangan perusahaan, khususnya aset tetap disajikan dengan kondisi nilai sebenarnya dan hal tersebut dapat mencerminkan kemampuan perusahaan yang sesungguhnya (Katuuk, 2013). Selain itu penerapan model revaluasi aset tetap dapat memberikan manfaat berupa penghematan pajak (Alamsyah, 2019).

\section{Revaluasi Aset Tetap Menurut Perpajakan}

Ketentuan perpajakan mengenai revaluasi aset tetap diatur dalam Peraturan Menteri Keuangan Republik Indonesia Nomor 79/PMK.03/2008. Menurut PMK RI Nomor 79 Tahun 2008 tersebut, revaluasi aset tetap secara perpajakan dilakukan setiap 5 tahun 
sekali. Hal ini menjelaskan bahwa terdapat perbedaan frekuensi revaluasi aset tetap secara akuntansi dan perpajakan. Peraturan tersebut juga menjelaskan bahwa surplus atas revaluasi aset tetap dikenakan pajak penghasilan yang bersifat final dengan tarif sebesar $10 \%$. Surplus revaluasi yang dimaksud adalah selisih nilai lebih aset tetap hasil revaluasi di atas nilai sisa buku fiskal semula. Dengan demikian, perusahaan yang menerapkan revaluasi aset tetap akan dikenakan $\mathrm{PPh}$ final atas surplus revaluasinya.

$\begin{array}{ccr}\text { Peraturan } & \begin{array}{c}\text { Menteri } \\ \text { Republik }\end{array} \text { Indonesia } & \text { Nomor }\end{array}$
191/PMK.010/2015 muncul sebagai tindak lanjut dari PMK RI Nomor 79 Tahun 2008 yang dirasa memberatkan perusahaan dalam melakukan revaluasi aset tetap. Menurut PMK RI Nomor 191 Tahun 2015 tersebut, keuntungan atau surplus revaluasi dikenakan $\mathrm{PPh}$ final yang tarifnya didasarkan atas permohonan pengajuan revaluasi aset tetap dengan ketentuan sebagai berikut:

Tabel 2

Tarif PPh Final Revaluasi Aset Tetap (PMK No. 191/2015)

\begin{tabular}{|l|c|}
\hline \begin{tabular}{|} 
Waktu Pengajuan \\
Revaluasi Aset Tetap
\end{tabular} & $\begin{array}{c}\text { Tarif PPh } \\
\text { Final }\end{array}$ \\
\hline $\begin{array}{l}\text { Sejak berlakunya PMK s.d. } \\
\text { 31 Desember 2015 }\end{array}$ & $3 \%$ \\
\hline $\begin{array}{l}\text { 1 Januari 2016 } \\
\text { 2016.d. 30 Juni }\end{array}$ & $4 \%$ \\
\hline $\begin{array}{l}\text { 1 Juli 2016 s.d. 31 } \\
\text { Desember 2016 }\end{array}$ & $6 \%$ \\
\hline Mulai 1 Januari 2017 & $10 \%$ \\
\hline Sumber: PMK RI Nomor
\end{tabular}

191/PMK.010/2015.

Perbedaan antara PMK RI Nomor 79 Tahun 2008 dan PMK RI Nomor 191 Tahun 2015 tidak terletak pada aspek tarif pajak penghasilannya saja, namun terdapat perbedaan-perbedaan dari aspek lainnya. Berikut merupakan beberapa perbedaan mengenai revaluasi aset tetap berdasarkan
PMK RI Nomor 191/PMK.010/2015 dan PMK RI Nomor 79/PMK.03/2008:

Tabel 3

Perbedaan PMK 191/2015 dan PMK 79/2008

\begin{tabular}{|c|c|c|}
\hline Aspek & $\begin{array}{l}\text { PMK RI No. } \\
\text { 191/PMK.010/2 } \\
\text { 015 }\end{array}$ & $\begin{array}{c}\text { PMK RI } \\
\text { Nomor } \\
\text { 79/PMK.03/2 } \\
008\end{array}$ \\
\hline Tarif & $3 \%, 4 \%, 5 \%$ & $10 \%$ \\
\hline $\begin{array}{l}\text { Dasar } \\
\text { Penge- } \\
\text { naan } \\
\text { Pajak }\end{array}$ & $\begin{array}{l}\text { Selisih nilai } \\
\text { lebih aset tetap } \\
\text { hasil revaluasi } \\
\text { di atas nilai } \\
\text { sisa buku } \\
\text { fiskal semula }\end{array}$ & $\begin{array}{l}\text { Selisih nilai } \\
\text { lebih aset } \\
\text { tetap hasil } \\
\text { revaluasi di } \\
\text { atas nilai sisa } \\
\text { buku fiskal } \\
\text { semula }\end{array}$ \\
\hline $\begin{array}{l}\text { Penilai } \\
\text {-an } \\
\text { aset } \\
\text { tetap }\end{array}$ & $\begin{array}{c}\text { Sebagian atau } \\
\text { seluruh aset } \\
\text { tetap }\end{array}$ & $\begin{array}{l}\text { Seluruh aset } \\
\text { tetap }\end{array}$ \\
\hline $\begin{array}{l}\text { Waktu } \\
\text { penyu- } \\
\text { sutan }\end{array}$ & $\begin{array}{l}\text { Saat } 1 \text { Januari } \\
2016 \text { bagi } \\
\text { Wajib Pajak } \\
\text { yang } \\
\text { melakukan } \\
\text { revaluasi pada } \\
\text { tahun 2015, } \\
\text { namun saat } \\
\text { bulan } \\
\text { dilakukannya } \\
\text { revaluasi bagi } \\
\text { Wajib Pajak } \\
\text { yang } \\
\text { melakukan } \\
\text { revaluasi pada } \\
\text { tahun } 2016 \\
\text { dan } 2017 \\
\end{array}$ & $\begin{array}{c}\text { Bulan } \\
\text { dilakukan- } \\
\text { nya revaluasi }\end{array}$ \\
\hline $\begin{array}{c}\text { Pajak } \\
\text { Teruta } \\
\text { ng }\end{array}$ & $\begin{array}{l}\text { Dilunasi } \\
\text { sebelum } \\
\text { mengajukan } \\
\text { permohonan } \\
\text { revaluasi } \\
\end{array}$ & $\begin{array}{l}\text { Dilunasi } 15 \\
\text { hari setelah } \\
\text { dikeluarkan } \\
\text { persetujuan } \\
\text { revaluasi } \\
\end{array}$ \\
\hline
\end{tabular}




\section{Tabel 3 (Lanjutan) \\ Perbedaan PMK 191/2015 dan PMK 79/2008}

\begin{tabular}{|c|c|c|}
\hline Aspek & $\begin{array}{c}\text { PMK RI No. } \\
\text { 191/PMK.01 } \\
\text { 0/2015 }\end{array}$ & $\begin{array}{c}\text { PMK RI } \\
\text { Nomor } \\
\text { 79/PMK.03 } \\
\text { /2008 }\end{array}$ \\
\hline Angsuran & $\begin{array}{c}\text { Tidak dapat } \\
\text { diangsur }\end{array}$ & $\begin{array}{l}\text { Paling lama } \\
12 \text { bulan }\end{array}$ \\
\hline $\begin{array}{c}\text { Jangka } \\
\text { waktu } \\
\text { penilaia } \\
\text { n ahli } \\
\text { penilai } \\
\text { dengan } \\
\text { penga- } \\
\text { juan } \\
\text { permoho } \\
\text { nan } \\
\text { revalu- } \\
\text { asi }\end{array}$ & $\begin{array}{c}\text { Pengajuan } \\
\text { permohonan } \\
\text { tahun } 2015 \\
\text { mengguna- } \\
\text { kan laporan } \\
\text { ahli penilai } \\
\text { tahun 2015, } \\
\text { sedangkan } \\
\text { pengajuan } \\
\text { permohonan } \\
\text { tahun 2016 } \\
\text { mengguna- } \\
\text { kan laporan } \\
\text { ahli penilai } \\
\text { tahun 2016 }\end{array}$ & $\begin{array}{c}\text { Pengajuan } \\
\text { permohon- } \\
\text { an revaluasi } \\
\text { paling lama } \\
1 \text { tahun } \\
\text { sebelum- } \\
\text { nya }\end{array}$ \\
\hline
\end{tabular}

Sumber: Atikasari dan Handayani (2017)

\section{Penelitian Terdahulu}

Penelitian yang membahas dan memberikan gambaran mengenai perkembangan jumlah perusahaan di Indonesia yang telah menerapkan revaluasi aset tetap masih sangat sedikit. Penelitian terkait jumlah perusahaan di Indonesia yang menerapkan revaluasi aset tetap telah dilakukan oleh Zakaria (2011). Penelitiannya dilakukan terhadap beberapa perusahaan yang terdaftar pada Bursa Efek Indonesia selama tahun 2008 dan 2009. Jumlah perusahaan yang diteliti dalam penelitian Zakaria (2011) berjumlah 93 perusahaan. Hasil penelitiannya menunjukkan bahwa seluruh perusahaan yang diteliti masih memilih untuk menggunakan model biaya sebagai model pengukuran aset tetapnya. Hal ini menunjukkan bahwa selama periode adopsi IFRS, perusahaan Indonesia masih menggunakan model biaya meskipun model revaluasi sudah diperkenankan.
Penyebabnya karena perusahaan masih menimbang-nimbang manfaat dan biaya dari menerapkan model revaluasi aset tetap sehingga belum siap dalam menerapkan model tersebut dalam pengukuran aset tetapnya.

\section{Metode Penelitian}

Penelitian yang dilakukan ini merupakan penelitian deskriptif analitis. Penelitian deskriptif merupakan penelitian yang dilakukan dengan tujuan untuk memberikan gambaran mengenai suatu hal (Pribadi dan Nurmiati, 2016). Dalam penelitian ini, hal yang ingin digambarkan adalah jumlah perusahaan yang menerapkan model biaya dan model revaluasi yang kemudian diolah dan dianalisis dalam rangka mengetahui metode penilaian aset tetap yang cenderung digunakan perusahaan-perusahaan manufaktur, khususnya pada periode setelah adopsi dan persiapan IFRS, yaitu pada periode implementasi IFRS serta menganalisis hal-hal yang mendasari penerapan metode penilaian aset tetap tersebut.

Penelitian ini dilakukan terhadap perusahaan-perusahaan yang terdaftar dalam Bursa Efek Indonesia dan masuk dalam sektor industri manufaktur selama 3 tahun berturut-turut dimulai dari tahun 2015 sampai dengan 2017. Jumlah perusahaan manufaktur yang diteliti seluruhnya berjumlah 117 perusahaan. Periode penelitian yang dilakukan adalah 3 tahun, mulai dari tahun 2015 sampai dengan 2017.

Analisis data dalam penelitian ini dilakukan berdasarkan deskripsi atas data yang telah dikumpulkan dan diolah. Pengolahan data berupa penghitungan frekuensi atas penerapan model biaya dan model revaluasi aset tetap. Setelah itu, peneliti akan melakukan perbandingan selama 3 tahun periode penelitian mengenai perkembangan model pengukuran aset tetap yang kemudian dideskripsikan dan dianalisis. 


\section{Hasil Penelitian dan Pembahasan}

\section{Hasil Penelitian}

Berdasarkan hasil pengumpulan data yang diperoleh dari laporan keuangan perusahaanperusahaan sektor manufaktur di Indonesia selama tahun 2015-2017, maka secara umum diperoleh informasi sebagai berikut:

Tabel 4

Jumlah Perusahaan Manufaktur Yang Menerapkan Cost Model dan Revaluation Model

\begin{tabular}{|c|c|c|c|}
\hline Model & \multicolumn{3}{|c|}{ Jumlah Perusahaan } \\
\cline { 2 - 4 } Penilaian & Tahun & Tahun & Tahun \\
Aset Tetap & $\mathbf{2 0 1 5}$ & $\mathbf{2 0 1 6}$ & $\mathbf{2 0 1 7}$ \\
\hline Cost Model & 101 & 98 & 95 \\
\hline $\begin{array}{c}\text { Revaluation } \\
\text { Model }\end{array}$ & 16 & 19 & 22 \\
\hline Total & $\mathbf{1 1 7}$ & $\mathbf{1 1 7}$ & $\mathbf{1 1 7}$ \\
\hline
\end{tabular}

Sumber: Hasil Pengolahan Data

Berdasarkan tabel 4, dapat dilihat bahwa perusahaan manufaktur yang diamati dalam penelitian ini berjumlah 117 perusahaan. Dari 117 perusahaan yang ada, sebanyak 101 perusahaan yang menerapkan Cost Model pada tahun 2015, 98 perusahaan yang menerapkan Cost Model pada tahun 2016, dan 95 perusahaan yang menerapkan Cost Model pada tahun 2017 untuk penyajian aset tetap dalam laporan keuangannya. Sedangkan untuk Revaluation Model, sebanyak 16 perusahaan yang menerapkannya pada tahun 2015, 19 perusahaan yang menerapkannya pada tahun 2016, dan 22 perusahaan yang menerapkannya pada tahun 2017 untuk keperluan penyajian aset tetap dalam laporan keuangan perusahaan. Apabila ditinjau dari kecenderungannya per tahun, penerapan Revaluation Model sebagai model penilaian aset tetap untuk pelaporan keuangan semakin meningkat dari tahun ke tahun dan secara bertahap bergeser ke arah penerapan Revaluation Model. Hal ini menunjukkan bahwa sekarang ini, masih banyak perusahaan manufaktur yang menggunakan 92
Cost Model, namun perlahan terdapat perusahaan yang beralih menjadi Revaluation Model dalam rangka penilaian aset tetap untuk kepentingan pelaporan keuangannya.

Perusahaan - perusahaan yang menerapkan Revaluation Model dapat dibagi menjadi perusahaan yang menerapkan Revaluation Model secara menyeluruh untuk seluruh aset tetapnya, namun ada juga yang menerapkan Revaluation Model hanya untuk sebagian aset tetapnya. Berdasarkan data yang dikumpulkan dari laporan keuangan, berikut merupakan jumlah perusahaan yang menerapkan revaluasi untuk seluruh aset tetapnya dan revaluasi untuk sebagian aset tetapnya:

\section{Tabel 5}

\section{Perusahaan Manufaktur Dengan Revaluation Model}

\begin{tabular}{|c|c|c|c|}
\hline Model & \multicolumn{3}{|c|}{ Jumlah Perusahaan } \\
\cline { 2 - 4 } $\begin{array}{c}\text { Penilaian } \\
\text { Aset Tetap }\end{array}$ & $\begin{array}{c}\text { Tahun } \\
\mathbf{2 0 1 5}\end{array}$ & $\begin{array}{c}\text { Tahun } \\
\mathbf{2 0 1 6}\end{array}$ & $\begin{array}{c}\text { Tahun } \\
\mathbf{2 0 1 7}\end{array}$ \\
\hline $\begin{array}{c}\text { Revaluation } \\
\text { Model } \\
\text { (sebagian) }\end{array}$ & 15 & 18 & 21 \\
\hline $\begin{array}{c}\text { Revaluation } \\
\text { Model } \\
\text { (penuh) }\end{array}$ & 1 & 1 & 1 \\
\hline Total & $\mathbf{1 6}$ & $\mathbf{1 9}$ & $\mathbf{2 2}$ \\
\hline
\end{tabular}

Sumber: Hasil Pengolahan Data

Berdasarkan tabel 5, dapat dilihat bahwa perusahaan manufaktur yang telah menerapkan Revaluation Model untuk seluruh jenis aset tetapnya hanya berjumlah satu perusahaan. Sedangkan, perusahaan manufaktur lain yang telah menerapkan Revaluation Model hanya melakukan revaluasi atas sebagian aset tetapnya saja dan bukan seluruh jenis aset tetapnya. Hal ini menunjukkan bahwa meskipun perusahaan manufaktur telah secara bertahap menggunakan Revaluation Model aset tetapnya untuk pelaporan keuangan, namun model tersebut masih dianggap sulit untuk penerapannya, apalagi jika diterapkan untuk 
seluruh jenis aset tetap yang dimiliki perusahaan.

$\begin{array}{ccr}\text { Peraturan } & \text { Menteri } & \text { Keuangan } \\ \text { Republik } & \text { Indonesia } & \text { Nomor }\end{array}$

191/PMK.010/2015 merupakan salah satu peraturan yang mendorong perusahaan untuk melakukan revaluasi aset tetapnya. Peraturan tersebut memberikan keringanan atas pembayaran PPh Final yang muncul sebagai akibat dari surplus revaluasi aset tetap. Dengan keringanan tersebut, perusahaan dapat menerapkan revaluasi aset tetap hanya untuk keperluan perpajakan, namun tetap menerapkan Cost Model untuk keperluan pelaporan keuangannya. Revaluasi aset tetap untuk keperluan perpajakan dilakukan setiap 5 tahun sekali, tidak seperti halnya revaluasi aset tetap untuk keperluan pelaporan keuangan yang harus dilakukan setiap kali terjadi perubahan yang signifikan atas nilai wajar aset tetap perusahaan pada akhir periode pelaporan.

Dengan adanya kebijakan perpajakan tersebut, maka beberapa perusahaan memutuskan untuk tetap menerapkan Cost Model, namun melakukan revaluasi aset tetapnya untuk keperluan perpajakan. Dengan hal tersebut, perusahaan mendapatkan manfaat dari revaluasi aset tetap secara perpajakan yaitu berupa pengakuan beban depresiasi yang lebih besar sehingga dapat mengurangi pajak penghasilan yang dibayarkan perusahaan ke pemerintah. Selain itu, perusahaan tidak perlu khawatir dalam melakukan penilaian nilai wajar aset tetap setiap akhir periode pelaporan karena penilaian aset tetap menurut perpajakan hanya dilakukan setiap 5 tahun sekali.

Berdasarkan data yang diperoleh dari pengungkapan laporan keuangan, berikut merupakan jumlah perusahaan yang menerapkan Cost Model namun melakukan revaluasi aset tetap secara perpajakan:

\section{Tabel 6 \\ Perusahaan Manufaktur yang Menerapkan Cost Model dan Revaluasi Secara Perpajakan}

\begin{tabular}{|c|c|c|c|}
\hline & $\begin{array}{c}\text { Tahun } \\
\mathbf{2 0 1 5}\end{array}$ & $\begin{array}{c}\text { Tahun } \\
\mathbf{2 0 1 6}\end{array}$ & $\begin{array}{c}\text { Tahun } \\
\mathbf{2 0 1 7}\end{array}$ \\
\hline $\begin{array}{c}\text { Cost Model } \\
\text { (Tanpa } \\
\text { Revaluasi } \\
\text { Secara } \\
\text { Perpajakan) }\end{array}$ & 92 & 88 & 95 \\
\hline $\begin{array}{c}\text { Cost Model } \\
\text { (Dengan } \\
\text { Revaluasi } \\
\text { Secara } \\
\text { Perpajakan) }\end{array}$ & 9 & 10 & 0 \\
\hline Total & $\mathbf{1 0 1}$ & $\mathbf{9 8}$ & $\mathbf{9 5}$ \\
\hline
\end{tabular}

Sumber: Hasil Pengolahan Data

Berdasarkan tabel 6, dapat dilihat bahwa jumlah perusahaan manufaktur yang menerapkan revaluasi aset tetap untuk keperluan perpajakan, namun Cost Model untuk pelaporan keuangan adalah 9 perusahaan untuk tahun 2015 dan 10 perusahaan untuk tahun 2016. Hal ini mengingat munculnya Peraturan Menteri Keuangan Republik Indonesia Nomor 191/PMK.010/2015 pada tahun 2015 yang memberikan kesempatan kepada perusahaan yang melakukan revaluasi aset tetap secara perpajakan untuk membayar $\mathrm{PPh}$ final atas surplus revaluasi hanya dengan tarif $3-6 \%$ dari besarnya surplus revaluasi. Revaluasi aset tetap secara perpajakan yang dilakukan pada periode tahun 2017 dikenakan PPh final dengan tarif seperti peraturan yang berlaku sebelumnya, yaitu 10\% dari surplus revaluasi. Oleh sebab itu, hal tersebut memotivasi manajemen perusahaan untuk melakukan revaluasi aset tetap pada tahun 2015 dan 2016, yaitu pada saat tarif PPh final yang dikenakan atas surplus revaluasi bernilai kecil.

Apabila ditinjau berdasarkan kategori sektor industri dan sub sektor industri yang tergolong dalam klasifikasi sektor manufaktur, maka jumlah perusahaan yang 
menerapkan Cost Model dan Revaluation Model selama tahun 2015 - 2017 dapat ditunjukkan dengan hasil sebagai berikut:

\section{Tabel 7}

Jumlah Perusahaan Manufaktur Yang Menerapkan Cost Model dan Revaluation Model Per Sektor Industri Manufaktur

\begin{tabular}{|c|c|c|c|}
\hline \multirow{2}{*}{$\begin{array}{c}\text { Model } \\
\text { Penilaian } \\
\text { Aset Tetap }\end{array}$} & \multicolumn{3}{|c|}{ Jumlah Perusahaan } \\
\hline & $\begin{array}{c}\text { Tahun } \\
2015\end{array}$ & $\begin{array}{c}\text { Tahun } \\
2016\end{array}$ & $\begin{array}{c}\text { Tahun } \\
2017\end{array}$ \\
\hline \multicolumn{4}{|c|}{ 1. Sektor Industri Dasar dan Kimia } \\
\hline Cost Model & 42 & 40 & 40 \\
\hline $\begin{array}{c}\text { Revaluation } \\
\text { Model }\end{array}$ & 10 & 12 & 12 \\
\hline Total & 52 & 52 & 52 \\
\hline \multicolumn{4}{|c|}{ 2. Sektor Aneka Industri } \\
\hline Cost Model & 29 & 29 & 26 \\
\hline $\begin{array}{c}\text { Revaluation } \\
\text { Model }\end{array}$ & 4 & 4 & 7 \\
\hline Total & 33 & 33 & 33 \\
\hline \multicolumn{3}{|c|}{$\begin{array}{ll}\text { 3. Sektor } \\
\text { Konsumsi }\end{array}$} & Barang \\
\hline Cost Model & 30 & 29 & 29 \\
\hline $\begin{array}{c}\text { Revaluation } \\
\text { Model }\end{array}$ & 2 & 3 & 3 \\
\hline Total & 32 & 32 & 32 \\
\hline
\end{tabular}

Sumber: Hasil Pengolahan Data

Berdasarkan tabel 7, dapat dilihat bahwa penerapan model revaluasi untuk penilaian aset tetap dari perusahaan yang bergerak dalam sektor manufaktur mengalami peningkatan selama rentang tahun 2015 sampai dengan 2017. Pada sektor industri dasar dan kimia, jumlah perusahaan yang menggunakan model revaluasi aset tetap adalah 10 perusahaan pada tahun 2015 dan bertambah menjadi 12 perusahaan pada tahun 2016 dan 2017. Begitu pula halnya dengan sektor industri aneka industri, jumlah perusahaan yang menggunakan model revaluasi aset tetap adalah 4 perusahaan pada tahun 2015 dan 2016. Jumlah ini meningkat menjadi 7 perusahaan pada tahun 2017 . Untuk sektor industri barang konsumsi, jumlah perusahaan yang menggunakan model revaluasi aset tetap adalah 2 perusahaan pada tahun 2015 dan meningkat menjadi 3 perusahaan pada tahun 2016 dan 2017.

\section{Pembahasan}

Berdasarkan hasil penelitian yang telah dijelaskan, maka dapat dilihat bahwa manajemen perusahaan manufaktur sudah memiliki kesadaran akan pentingnya penyajian informasi laporan keuangan yang relevan, salah satunya terkait informasi aset tetap. Hal ini tampak dari adanya peningkatan jumlah perusahaan yang menggunakan model revaluasi aset tetap. Meskipun peningkatan jumlah perusahaan yang menggunakan model revaluasi aset tetap tidak terlalu signifikan, namun adanya peningkatan jumlah perusahaan yang secara bertahap menunjukkan semakin sadarnya manajemen perusahaan manufaktur untuk menyajikan informasi aset tetap yang lebih bersifat relevan.

Dari beberapa perusahaan manufaktur yang telah menerapkan model revaluasi untuk penyajian aset tetapnya, hanya ada 1 perusahaan yang menerapkan model revaluasi aset tetap secara penuh. Dengan demikian, jumlah perusahaan manufaktur yang melakukan revaluasi untuk seluruh jenis aset tetapnya masih berjumlah sangat sedikit. Hal ini disebabkan karena sebagian besar manajemen perusahaan merasa bahwa biaya untuk menerapkan model revaluasi aset tetap lebih besar daripada manfaat yang diperolehnya. Hal ini sesuai dengan penelitian yang dilakukan Zakaria (2011) dimana perusahaan masih menimbang dan merasa biaya untuk menerapkan model revaluasi aset tetap tidak sebanding dengan manfaat yang diberikannya. Untuk menerapkan model revaluasi aset tetap, perusahaan harus menentukan nilai wajar aset tetap pada tanggal pelaporan. Penentuan nilai wajar bersifat subjektif karena setiap aset tetap memiliki kondisi yang berbeda-beda sehingga penentuan nilai wajarnya menjadi 
sulit dan menghabiskan waktu. Seringkali manajemen perusahaan tidak mendapatkan harga atau nilai yang representatif sebagai nilai wajar dari aset tetapnya. Oleh karena itu, perusahaan yang menggunakan model revaluasi biasanya meminta bantuan jasa penilai untuk menentukan nilai wajar dari aset tetap sehingga menimbulkan biaya (Latifa \& Haridhi, 2016).

Manfaat dari penerapan model revaluasi adalah dihasilkannya informasi yang lebih berkualitas bagi pengguna laporan keuangan untuk pengambilan keputusan. Informasi menjadi relevan karena informasi aset disajikan sebesar nilai wajar yang merefleksikan nilai saat ini, bukan nilai historis seperti halnya aset tetap yang disajikan menggunakan model biaya. Selain itu, manfaat lainnya adalah memberikan kesempatan bagi perusahaan untuk memperoleh dana pinjaman yang lebih besar dari lembaga keuangan karena dengan revaluasi aset tetap terdapat peluang bahwa nilai aset dan ekuitas perusahaan meningkat (Kumala, 2015). Hal ini dapat memberikan tanda yang positif bagi pihak eksternal perusahaan karena dianggap mendorong peningkatan kinerja perusahaan yang dicerminkan melalui laba dan harga saham perusahaan (Hidayat \& Hati, 2017).

Manfaat dari penerapan model revaluasi aset tetap di perusahaan manufaktur masih dirasa bersifat kualitatif dan belum dapat terukur secara jelas. Di sisi lain, biaya dari penerapannya bersifat terukur dan jelas sehingga perusahaan merasa biaya dari penerapan model revaluasi aset tetap masih lebih besar daripada manfaatnya. Sebagai dampaknya, perusahaan manufaktur seolah berusaha untuk mencari jalan tengah terkait isu revaluasi aset tetap ini, yaitu dengan menerapkan revaluasi sebagian. Dengan demikian, mayoritas perusahaan manufaktur yang menggunakan model revaluasi untuk penyajian aset tetapnya menerapkan revaluasi sebagian. Dengan revaluasi sebagian ini, perusahaan hanya menerapkan revaluasi untuk jenis aset tetap tertentu sehingga diharapkan manfaat dan biaya yang diterima lebih sebanding.

Dengan adanya penerapan revaluasi sebagian dari aset tetap, maka peran jasa penilai aset semakin dibutuhkan, khususnya pada perusahaan manufaktur di Indonesia. Oleh karena itu, sumber daya manusia yang ada di Indonesia harus diberikan pendidikan mengenai penilaian wajar aset tetap sehingga meningkatkan jumlah supply dari sumber daya manusia Indonesia yang memahami penilaian wajar aset tetap di tengah terjadinya peningkatan demand atas jasa penilai aset tetap. Dengan seimbangnya supply dan demand dari jasa penilai aset tetap, diharapkan biaya dari jasa penilai dapat dikurangi sehingga semakin banyak perusahaan di Indonesia yang akan menerapkan model revaluasi aset tetap. Dengan demikian, relevansi informasi dalam laporan keuangan dapat ditingkatkan.

\section{Simpulan dan Saran}

\section{Simpulan}

Berdasarkan hasil dan pembahasan penelitian, maka dapat dilihat bahwa sebagian besar dari emiten yang bergerak dalam sektor industri manufaktur di Indonesia masih menggunakan model biaya dalam penyajian aset tetap di laporan keuangannya. Sebagian manajemen perusahaan manufaktur menyadari manfaat revaluasi aset tetap, sehingga beberapa dari perusahaan manufaktur di Indonesia melakukan revaluasi aset tetap secara perpajakan meskipun penyajian aset tetap dalam laporan keuangannya tetap menggunakan model biaya.

Selama tahun 2015 - 2017, beberapa emiten yang bergerak dalam sektor industri manufaktur telah menerapkan model revaluasi dalam penyajian aset tetapnya di laporan keuangan. Meskipun masih berjumlah sedikit, penerapan model revaluasi ini memiliki kecenderungan meningkat setiap periodenya pada sektor industri manufaktur. Hal ini 
menggambarkan bahwa pada periode implementasi IFRS semakin muncul kesadaran dari manajemen perusahaan manufaktur di Indonesia untuk menyajikan informasi laporan keuangan yang lebih berkualitas dan relevan sehingga dapat memberikan manfaat bagi perusahaan maupun pengguna laporan keuangan dari pihak eksternal perusahaan.

Mayoritas emiten yang bergerak dalam sektor industri manufaktur di Indonesia menggunakan model biaya dalam penyajian aset tetapnya. Manajemen perusahaan merasa bahwa biaya dari penerapan model biaya lebih kecil dibandingkan penerapan model revaluasi aset tetap. Hal ini disebabkan karena penerapan model revaluasi lebih sulit dan membutuhkan pengukuran nilai wajar terkait aset tetapnya. Pengukuran nilai wajar aset tetap seringkali menggunakan bantuan jasa penilai yang menyebabkan biaya dan penerapannya lebih sulit dibandingkan model biaya. Di sisi lain, manfaat dari penerapan model revaluasi aset tetap dirasa masih belum dapat terukur secara andal sehingga mayoritas perusahaan masih merasa enggan untuk menerapkan model revaluasi untuk kepentingan pelaporan keuangan terkait aset tetapnya.

\section{Saran}

Beberapa saran yang kiranya dapat diberikan terkait dengan hasil penelitian ini adalah sebagai berikut:

1) Perusahaan sebaiknya memberikan pelatihan bagi akuntan perusahaannya mengenai teknik penilaian aset tetap sehingga perusahaan dapat meminimalkan penggunaan jasa penilai dari pihak eksternal dan dapat mengurangi biaya perusahaan yang menerapkan model revaluasi aset tetap.

2) Pemerintah sebaiknya dapat lebih memotivasi perusahaan-perusahaan untuk menerapkan revaluasi aset tetap dalam pelaporan keuangan karena pelaporan aset tetap dengan model revaluasi menyajikan informasi keuangan perusahaan yang lebih relevan. Pemerintah dapat bekerjasama dengan Ikatan Akuntan Indonesia (IAI) untuk memberikan pemahaman yang lebih mendalam bagi manajemen perusahaan mengenai revaluasi aset tetap dan manfaatnya.

\section{Daftar Pustaka}

Alamsyah, A. R. (2019). Penerapan Perencanaan Pajak Melalui Metode Penyusutan dan Revaluasi Aset Tetap. JRAM (Jurnal Riset dan Aplikasi: Akuntansi dan Manajemen), 3(3): 189204.

Aryani, F.A., \& Juliarto, A. (2017). Relevansi Nilai Revaluasi Aset Tetap Dengan Tingkat Utang Sebagai Variabel Moderasi. Jurnal Akuntansi dan Auditing, 14(1): 1-21.

Atikasari, T. T. \& Handayani, N. (2017). Dampak Revaluasi Aset Tetap Terhadap Pajak Penghasilan yang Terutang. Jurnal Ilmu dan Riset Akuntansi, 6(8): 1 - 15.

Baker, P.S. (2011). An Examination of Potential Changes in Ratio Measurements Historical Cost versus Fair Value Measurement in Valuing Tangible Operational Assets. Journal of Accounting and Finance, 11(2): 170 $-176$.

Christensen, H. B. dan Nikolaev, V.V. (2013). Does Fair Value Accounting for Non-Financial Assets Pass The Market Test?. Review of Accounting Studies, 18(3): $734-775$.

Clarkson, et.al. (2011). The Impact of IFRS Adoption on The Value Relevance of Book Value and Earnings. Journal of Contemporary Accounting \& Economics. 7(1): 1 - 17.

Gunawan, F. \& Nuswandari, C. (2019). Likuiditas, Leverage, Fixed Assets Intensity, Arus Kas Operasi, dan Ukuran Perusahaan Terhadap Pemilihan Model Revaluasi Aset Tetap 
(Studi Empiris pada Perusahaan Manufaktur yang Terdaftar di Bursa Efek Indonesia Periode 2013-2017). Dinamika Akuntansi, Keuangan, dan Perbankan, 8(1): 1-11.

Hidayat, M. \& Hati, R. P. (2017). The Choosing of Fixed Asset Revaluation Models and Its Effects on Company Value in Banking Sector. Dimensi, 6(3): 362-379.

Ikatan Akuntan Indonesia. (2017). Standar Akuntansi Keuangan, Jakarta: Salemba Empat.

Jackling, B., et.al. (2012). Some Implications of IFRS Adoption for Accounting Education. Australian Accounting Review, 22(4): 331 - 340.

Katuuk. Y. C. (2013). Analisis Perencanaan Pajak Melalui Revaluasi Aktiva Tetap pada PT. Angkasa Pura I (Persero) Bandara Sam Ratulangi. Jurnal EMBA, 1(3): 540-550.

Kumala, F. (2015). Metode Analisis Perbandingan Pengukuran Aset Tetap antara Model Biaya dan Model Revaluasi pada PT. X. Jurnal Ilmiah Universitas Bakrie, 3(3).

Latifa, C., A. \& Haridhi, M., (2016). Pengaruh Negosiasi Debt Contracts, Political Cost, Fixed Asset Intensity, dan Market to Book Ratio Terhadap Perusahaan Melakukan Aset Tetap (Studi pada Perusahaan Manufaktur yang Terdaftar di Bursa Efek Indonesia Tahun 2010-2014). Jurnal Ilmiah Mahasiswa Ekonomi Akuntansi (JIMEKA), 1(2): 166-176.

Maria, E. (2010). Penerapan PSAK 16 (Revisi 2007) dan PMK No. 79 Tahun 2008 Tentang Aset Tetap Pada Perusahaan di Indonesia. Jurnal Ilmiah untuk Peningkatan Profesional, 3(1): $75-83$.

Menteri Keuangan Republik Indonesia. (2008). Peraturan Menteri Keuangan Republik Indonesia Nomor 79/PMK.03/2008 Tentang Penilaian Kembali Aktiva Tetap Perusahaan Untuk Tujuan Perpajakan, https://staff.blog.ui.ac.id/martani/files/ 2013/02/PPh-Badan-PMK-79-Tahun2008-Revaluasi.pdf diakses 4 Juni 2018.

Menteri Keuangan Republik Indonesia. (2015). Peraturan Menteri Keuangan Republik Indonesia Nomor 191/PMK.010/2015 Tentang Penilaian Kembali Aktiva Tetap Untuk Tujuan Perpajakan Bagi Permohonan Yang Diajukan Pada Tahun 2015 dan 2016, http://www.jdih.kemenkeu.go.id/fullT ext/2015/191 PMK.010 2015Per.pdf diakses 4 Juni 2018.

Pribadi, C. \& Nurmiati. (2016). Analisis Perbandingan Atas Model Revaluasi Aset Tetap Sesuai PSAK No. 16 (Revisi 2007) dan Dampak Perpajakannya Menurut UndangUndang Pajak. JIAFE (Jurnal Ilmiah Akuntansi Fakultas Ekonomi), 2(1): 38-57.

Rahmawati, L. \& Murtini, H. (2015). Kualitas Informasi Akuntansi Pra dan Pasca Adopsi IFRS. Accounting Analysis Journal, 4(2). https://doi.org/https://doi.org/10.1529 4/aaj.v4i2.7861.

Saputra, B. W. \& Hermawan, A. (2012). Perkembangan International Financial Reporting Standard (IFRS) dan Penerapannya di Indonesia. Finance \& Accounting Journal, 1(1): 15 - 22.

Wijaya, C. F. (2020). Pengaruh Likuiditas, Struktur Modal, Ukuran Perusahaan, Prospek Pertumbuhan, Kualitas Audit Terhadap Kualitas Laba Perusahaan Batu Bara. JEMAP: Jurnal Ekonomi, Manajemen, Akuntansi, dan Perpajakan, 3(2): 206-226.

Wulandari, T. R. \& Adiati, A. K. (2015). Perubahan Relevansi Nilai Dalam Informasi Akuntansi Setelah Adopsi IFRS. Jurnal Akuntansi Multiparadigma (JAMAL), 6(3): 341511. 
Jurnal Akuntansi匹 Volume 13 Nomor 1, Mei 2021 : 84 - 98

Zakaria, A. (2011). The Early Adoption of Cost or Revaluation Model for Property, Plant, and Equipment in Indonesia. Cambridge Business \& Economic Conference. 